\title{
Investigating International Students' Perception of Foodservice Attributes in Malaysian Research Universities
}

\author{
Anisa Zahwa Akbara ${ }^{1}$, Bee-Lia Chua ${ }^{1, * \mathbb{C}}$, Heesup Han ${ }^{2, * \mathbb{C}}$ and António Raposo ${ }^{3} \mathbb{C}$ \\ 1 Department of Food Service and Management, Faculty of Food Science and Technology, \\ Universiti Putra Malaysia, Serdang 43400, Malaysia; akbarazahwa@gmail.com \\ 2 College of Hospitality and Tourism Management, Sejong University, 98 Gunja-Dong, Gwanjin-Gu, \\ Seoul 143-747, Korea \\ 3 CBIOS (Research Center for Biosciences and Health Technologies), Universidade Lusófona de Humanidades \\ e Tecnologias, Campo Grande 376, 1749-024 Lisboa, Portugal; antonio.raposo@ulusofona.pt \\ * Correspondence: chuabeelia@upm.edu.my (B.-L.C.); heesup.han@gmail.com (H.H.)
}

Citation: Akbara, A.Z.; Chua, B.-L.; Han, H.; Raposo, A. Investigating International Students' Perception of Foodservice Attributes in Malaysian Research Universities. Sustainability 2021, 13, 8190. https://doi.org/ $10.3390 /$ su13158190

Academic Editor: Marian Rizov

Received: 16 June 2021

Accepted: 17 July 2021

Published: 22 July 2021

Publisher's Note: MDPI stays neutral with regard to jurisdictional claims in published maps and institutional affiliations.

Copyright: (c) 2021 by the authors. Licensee MDPI, Basel, Switzerland. This article is an open access article distributed under the terms and conditions of the Creative Commons Attribution (CC BY) license (https:// creativecommons.org/licenses/by/ $4.0 /)$.

\begin{abstract}
University foodservice is expected to satisfy students' food needs and is one of the necessities at a university. However, serving a community of international students who are multicultural is not an easy task. Thus, it is necessary to recognize international students' needs and wants in order to increase their satisfaction with the overall on-campus dining experience. This study conducted an importance-performance analysis to examine international students' perceived importance and perceived performance of university foodservice attributes. Using a self-administered questionnaire, a total of 620 international students who were studying in Malaysian research universities comprised the sample of this study. The results showed that food price was the most satisfactory foodservice attribute as perceived by international students. Food quality was deemed unsatisfactory and represented the main weakness. Results from this study can assist in determining how international students perceive the quality of the key attributes of on-campus foodservices and identify fields in which improvements are required.
\end{abstract}

Keywords: university foodservice attributes; importance-performance analysis (IPA); international students; Malaysian research universities

\section{Introduction}

The admissions of global students remain important to the university sector in Malaysia, since Malaysia sought to be acknowledged as a world-class higher education center by the year 2020 [1]. Moreover, foreign students also generate international business possibilities and ties to world trade, become diplomatic allies, and encourage interest in foreign policy [2]. However, to maintain international students in this competitive setting, significant efforts are needed. Efforts were made to attract foreign students by improving the reputation of Malaysian higher education institutions. Therefore, the Malaysian Research Universities (MRU) program has provided Malaysian universities and research institutions with an awareness of the research culture. Among the initiatives are (1) targeting the enrolment of global students, (2) improving Malaysian universities' world ranking, (3) creating more "Malaysian chairs" at universities overseas, and (4) collaborating and cooperating on research and educational issues with world-renowned universities [3]. In addition to these goals, superior service to meet student needs and expectations and maintain student satisfaction and loyalty to their chosen study destinations have become a core objective of these colleges $[2,4]$.

According to Ezeokoli and Ayodele [5], the quality of foodservice is acknowledged as a main academic excellence metric and a significant strategic variable to boost the market share of colleges and service providers, with enduring impacts on the organization and its students. Klassen, Trybus, and Kumar [6] added that foodservice is a fundamental factor 
that influences student satisfaction. Furthermore, previous studies have shown various foodservice attributes, such as food quality, price fairness, hygiene, food variety, service quality, food price, and ambience, that could predominantly influence university students' satisfaction [7-14]. The foodservice outlet is the primary form for student foodservice in colleges [15]. Drummond and Brefere [16] noted that food can make students become more focused on academic studies and ultimately can affect their academic performance. Therefore, in order to be a study destination for international students, evaluating the role of on-campus dining service is critically important.

University foodservice is one of the amenities that must be taken into consideration in order to accommodate students [17]. Students' preferences for food and services are changing. Students who are dissatisfied with the service quality of a university cafeteria will choose off-campus dining [18]. Most university foodservice operations are outsourced in this modern age, with independent food operators or food firms given a certain number of years of contract to operate the company on campus [19]. Independent operators also run restaurants, cafeterias, food courts, kiosks, vending machines, dining halls and stalls on university premises. This is also the case for Malaysian university foodservices [20]. Consequently, for university foodservice operators, it is important to understand students needs and satisfy their overall on-campus dining experience, even though some food operators are independent.

On the other hand, university foodservice operators in Malaysia have the most difficult task of serving a community of students who are multicultural and confined to the university environment [21]. Abdullah, Mansor, and Naba [22] found that students were generally dissatisfied with the food quality and price provided by university food operators. Liang and Zhang [15] discovered that the key factors contributing to student dissatisfaction when patronizing a university cafeteria were food quality, price, and value. Klassen, Trybus, and Kumar [6] identified that the most common complaints regarding university foodservice by international students were poor ambience, lack of resources, price, lack of food choices, and low food quality. In the context of university foodservice in Malaysia, there has been relatively limited empirical studies examining the importance and performance of foodservice attributes among international students in Malaysian research universities. To address this issue, this study analyzed the importance and performance of foodservice attributes perceived by international students in Malaysian research universities by utilizing the importance-performance analysis (IPA) method. This method is popular for evaluating service quality in a multitude of areas. IPA examines the "importance" individuals place on any given product/service attribute. Furthermore, the method has been employed in designing corporate marketing strategies, in guiding government planning choices, and in evaluating the organization and supervision of activities and schemes. The IPA method offers a pragmatic theoretical basis for important evaluation. The results of this study could be used to demonstrate which foodservice attributes need to be strategically planned and improved. The objectives of this study are as follows:

- To identify international students' perceived importance of on-campus dining attributes.

- To examine international students' perceived performance of on-campus dining attributes.

\section{Literature Review}

\subsection{University Foodservice Attributes}

Many studies have emphasized the effect on customer satisfaction of foodservices [17,19,23,24]. According to El-Said and Fathy [12], foodservice is an important component of overall planning that affects quality of life at university. Particularly, foodservice was verified as an important component of a healthy arrangement that affects the personal satisfaction of students and faculty at universities and colleges [25]. Kim, Lee, and Yuan [26] in their study of college students' satisfaction with university also confirmed that foodservice attributes influenced college student satisfaction.

Student-seller interaction is the type of communication that takes place in a university cafeteria. The interactions between the student and the foodservice personnel are important, 
as students can be highly sensitive [27]. Moreover, Chang and Suki [28] added that the staff performance was found to have a statistically significant impact on student satisfaction of the experience of student dining in the cafeteria. The performance of cafeteria employees is particularly important for students in terms of customer friendliness and responsiveness. Hence, interactional quality is an important factor for improving college student satisfaction [27]. Concerning the food quality of on-campus foodservice, Andaleeb and Caskey [10] found that most students noted that, were the food quality to improve, they would more often consider on-campus foodservices. Food quality is a feature of foods acceptable to customers and includes the appearance, smell, taste, and texture of foods [29]. In shaping and affecting customer satisfaction, quality is of essential importance. Customers are the primary drivers of customer satisfaction for food quality [30].

Students also consider cost when purchasing of food at the cafeteria as an important aspect of university foodservice. It is well known that students have limited budgets that affect their food choices; they are always looking for reasonable prices [31]. This is the first problem students have in college foodservice, because students buy food with limited resources, as Nadzirah, Ab-Karim, Ghazali, and Othman [21] claimed. The paid price should be appropriate for the amount of food served to students so that they feel they are getting good value the products and services, producing student satisfaction. The dining atmosphere can be regarded, according to Ha and Jang [32], as critical for affecting customer satisfaction levels, mainly because customer reactions to the setting form part of the consumer experience. For university foodservice, the spatial organization of the sitting, various internal decorations, and the suitability of the sound environment, which are essential to enhanced gratification, dictate the cafeteria atmosphere [33]. Chang and Suki [28] also added that cafeteria design affects the students' food decisions and eating behaviors.

In addition, McLachlan and Justice [34] explained that food selection was found to be an important part of the satisfaction of international students. It was defined as food supplied in on-campus foodservice that matches the culture, religion, taste, etc., of international students. Raman and Chinniah [27] also noted that the variety and diversity of food and comfort in university cafeterias gives students a sense of "home" while on campus. Nevertheless, empirical investigations on international students' perception of foodservice attributes in Malaysian research universities are relatively few. Therefore, this study aimed to demonstrate which foodservice attributes need to be strategically planned and improved as perceived by international students. Foodservice attributes in terms of interactional quality, food quality, atmospheric quality, food price, and food selection are employed in this study.

\subsection{International Students' University Life Adaptation and its Relation to University Foodservice}

International students are subjected to numerous changes and can struggle to adjust in a number of ways [35]. According to Andrade [36], international students experience more fear, stress, homesickness, loneliness, and lack of social support than domestic students. Thomas and Althen [37] also added that international students may experience a variety of transition issues, including depression/helplessness, hostility toward the host country, anxiety, over-identification with the home country, isolation, homesickness, and loneliness. Transitioning from parental care to independent living entails many novel decision-making experiences and choices, which can have a long-term influence on eating habits and health condition for students [38]. Lin and Yi [39], in agreement with the literature, reported that many foreign Asian students encounter the following when they study abroad: academic distress, language differences, financial concerns, performance anxiety, depression, loneliness, homesickness, relationship issues, non-assertiveness, individualism and bicultural tension, stereotyping, racism, bigotry, and fear. They may have anxieties about readjustment if they are intending to return to their own country. Specifically, there are several categories summarized by Tseng and Newton [40] as the main challenges encountered by international students: socio-cultural adjustment, personal psychological adjustment, 
academic adjustment, and general living adjustment. Socio-cultural change leads to culture shock, injustice, and adjusting to unfamiliar traditions, expectations, festivals, and rituals. Personal psychological adjustment is characterized by feelings of depression, solitude, alienation, homesickness, and dissatisfaction. Weather/climate adaptation, transportation systems, bill payment, health care systems, accommodation conditions, and food are examples of general living adjustments.

It has been argued that institutions should play a constructive approach in embracing and supporting global scholars in their academic and social adjustment. The more universities recognize the demands of foreign students, the more effective their students will be [41]. Furthermore, a satisfied student population is a source of favorable outcomes, such as spreading positive word of mouth and recommending the university to others. It can be impossible to obtain overall satisfaction if a negative attitude is formed; this could result in complaints, decreasing loyalty, and negative promotion by word of mouth [42]. Of particular interest to the present study is the fact that international students have discovered that food is a vital aspect of adjusting to Malaysia. International students rely on ethnic dishes from their home countries to alleviate homesickness anxiety [43]. McLachlan and Justice [34] identified food disparities as a component that aids foreign students in dealing with change overload and transformation shock. Furthermore, in order to reach and help international students adapt academically and socially, organizations have to take on a proactive approach. Garg [44] stated that many university administrators are starting to recognize the concept of offering comprehensive campus facilities that are essential to foodservices. Demand for foodservice has steadily increased, especially in universities, as the number of students continues to rise. As a consequence, these higher requirements for college foodservices have placed increasing pressure on operators to satisfy students requirements $[10,45]$. One of the primary objectives of universities is student satisfaction. According to Ruetzler, Taylor, and Hertzman [41], campus foodservice has a huge impact on the overall satisfaction of the student population. The canteens provide goods and services that can enhance the life of all those members of today's progressively varied university population with regard to social, financial, educational and personal fulfilment. Students expect greater levels of attention and more friendly service. For most customers, the food quality, cleanliness of the dining area, atmosphere, and freshness of the ingredients are satisfaction factors [46]. Amelia and Garg [9] also stated that the major factors of foodservice satisfaction are first impression, food quality, serving time, and employees. The satisfaction of students in university cafeterias depends entirely on the quality of the food and beverages served in cafeterias, the variety and choices of food and beverages, and fair price and value [9]. Campus administrators have stepped up their efforts to recruit and select only the most talented and experienced foodservice directors in response to this demand.

\subsection{Importance-Performance Analysis}

Initially established by Martilla and James [47], IPA provides ideas on what products or services a company should concentrate on in order to attain customer satisfaction. It examines quality attributes according to two measures: their effectiveness (satisfaction) and their value to customers (importance). The evaluation of these two dimensions is then combined with a matrix to determine the key factors of satisfaction, propose goals for improvement, and recognize areas of over-conformity and appropriate drawbacks [48]. To simplify data analysis, the IPA method incorporates measurement of consumer-perceived performance and importance into a two-dimensional matrix [47]. Figure 1 depicts a matrix that categorizes attributes into four groups or quadrants to establish goals in allocating finite resources. 


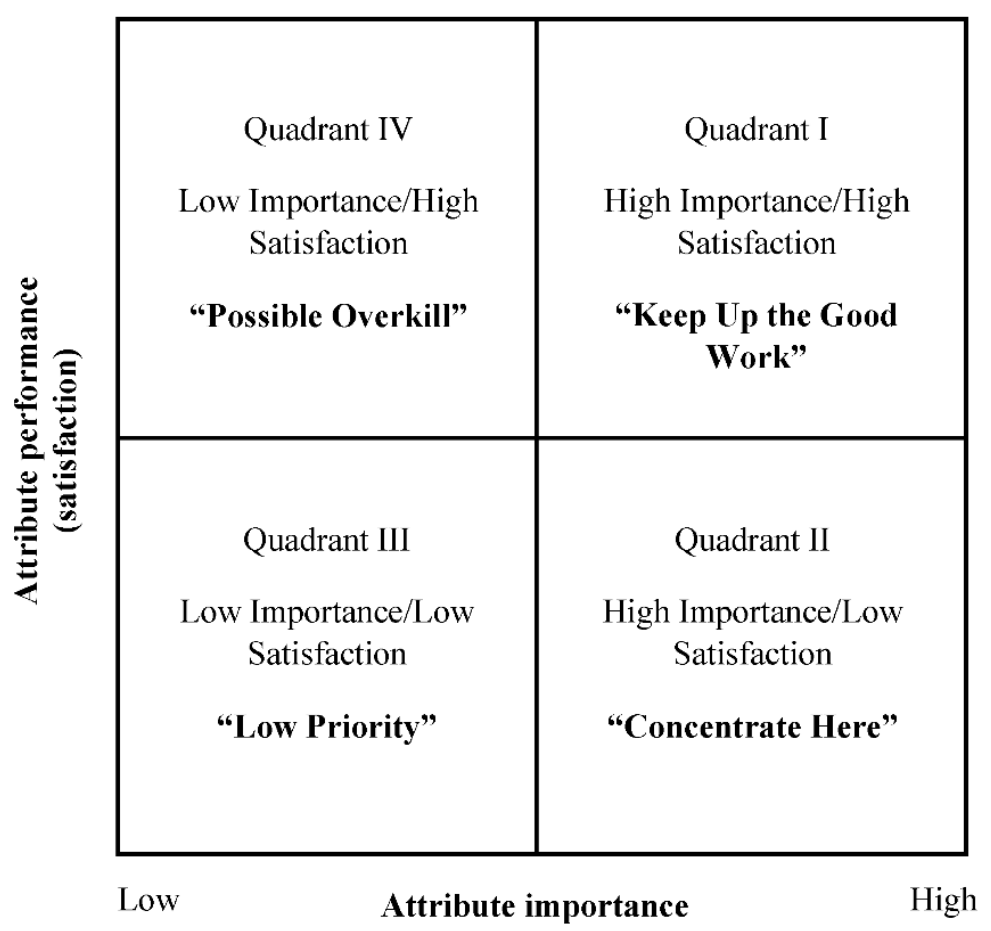

Figure 1. Importance-performance quadrants (Source: Matzlera et al. [48]).

Quadrant I, "keep up the good work", refers to the important strength of a product or service and the prospective competitive benefit. The characteristics in this quadrant are regarded to be successful and require continuous investment. Quadrant II is the "concentrate here" area. The attributes in this quadrant are deemed insufficient, constituting major shortcomings and risks to the product's competitiveness. Attributes in Quadrant III are deemed to be comparatively unimportant to consumers and fall under the "low priority" category. They are not doing exceptionally well or are considered to be relatively unimportant to customers. Quadrant IV is a relatively unimportant section of the matrix [48]. The "possible overkill" region includes characteristics that are of low value to consumers but work well, suggesting a possible excess of scarce resources that are being used inefficiently and should be reallocated elsewhere [48].

Previous studies [49-52] noted that the IPA method is a tool to assess the performance of the service factor level, which measures the importance and satisfaction of the service innovation process. The importance of measuring and managing customer satisfaction in foodservice is widely acknowledged [53]. The critical factors determining satisfaction and importance must be identified. The best way to attain the greatest level of satisfaction is to decide how scarce resources are deployed. The IPA method is seen as an efficient way to set priorities. The tool appears to be an easy and effective instrument in practice [54]. The decision on how best to allocate scarce funds to maximize satisfaction is very helpful. To maximize fulfillment, IPA is very helpful to decide how best to allot scarce resources. For example, Tzeng and Chang [55] used IPA to explore restaurant service quality. The results of their study provided the direction to improve the service quality in the foodservice industry. Gemmel [56] argued that the IPA technique can help administrators with improvements in order to achieve high customer satisfaction with service quality.

\section{Method}

\subsection{Measures and Development of Survey Instrument}

The research instrument of this study was a self-administered questionnaire. The questionnaire consisted of demographic questions and relevant measures. The "interactional quality" variable consisted of seven items, while six items were used to measure the "food quality" variable. The "atmospheric quality" variable was composed of six items. In addi- 
tion, there were three questions measuring the "food price" variable. The four variables were adapted from El-Said and Fathy [12] and Liang and Zhang [15]. The "food selection" variable consisted of five items, adjusted from Ruetzler, Taylor, and Hertzman [41]. Furthermore, all the measurement items were measured on a 7-point scale, ranging from level 1, which represented "very dissatisfied", to level 7, which signified "very satisfied". Another 7-point scale ranged from 1 , which represented "very unimportant", to 7, which signified "very important".

The mean scores of importance and satisfaction for foodservice attributes were obtained. These values then were used to analyze each element in the importance satisfaction grid as a plot. The vertical axis showed satisfaction of international students with the performance of service and service providers on a given attribute, ranging from highly dissatisfied to highly satisfied (7-point Likert scale). The horizontal axis, ranging from very unimportant to very important (7-point Likert scale), represented the importance of the attribute to international students. Satisfaction and importance scores of students were plotted on the IPA grid, which was constructed as the crossing point between mean values of the attribute ratings of importance and satisfaction. Four quadrants were generated by IPA, each with a different marketing strategy. Based on the quadrant in which it fell, each attribute was evaluated.

IPA plot interpretations followed each attribute's composite of importance and satisfaction scores. For instance, attributes high in importance and high in satisfaction proposed that university foodservice was doing a decent task and could continue to assign resources to these attributes. There may be little strategic advantage for additional investment. Particular attention should be paid to attributes of high importance and low satisfaction. A large amount of resources should be invested in improving the efficiency of the attributes. Lastly, low value and high satisfaction attributes could be protected by the university foodservice, but not explicitly allocated any extra funding.

\subsection{Validity and Reliability}

By using SPSS 20 for Windows, the validity analysis of this study was carried out by computing the correlations between individual items and the score sum of their respective construct. All the correlation coefficients between the items and their respective construct were statistically significant $(p<0.05)$. In this study, after the validity of the instrument was tested, it was distributed to subjects. The test result identified the coefficient of instrument reliability. The reliability coefficient of the instrument in this study was identified using Cronbach's alpha $(\alpha)$ coefficient. The reliability analysis results revealed that the measurement items of the instrument were reliable to measure the five key constructs: interactional quality, food quality, atmospheric quality, food price fairness, and food selection. The results defined that all five key constructs were reliable. The values were included in the very high reliability category $(0.80<\alpha<1.00)$.

\subsection{Data Collection and Samples}

The target population and unit analysis consisted of all full-time international postgraduate and undergraduate students enrolled in five public Malaysian Research Universities (MRUs) in Malaysia. They were Universiti Malaya (UM), Universiti Kebangsaan Malaysia (UKM), Universiti Sains Malaysia (USM), Universiti Putra Malaysia (UPM), and Universiti Teknologi Malaysia (UTM). Two stages of sampling techniques were used in this study: stratified sampling (stage 1) and purposive sampling (stage 2). The reason stratified sampling was chosen is because the population of this study was international students in MRUs. There are five separate research universities in Malaysia, and all have international students. Hence, a sample of international students from each university was taken. Subsequently, purposive sampling was done by searching the members (sample) of a group purposefully. Only subjects fit for the study purpose were selected. The inclusion criteria of the study subjects were (1) full-time undergraduate or postgraduate international student at a research university in Malaysia; (2) eating on campus at least three times 
at the same foodservice outlet (e.g., cafeteria, food stall) since enrolled at the university; (3) staying in university housing (e.g., hostel, apartment, dorm) at least one semester since enrolled at the university.

The survey was carried out for a 12-week period from 3 October 2018 to 27 December 2018. The questionnaire was distributed by paper-and-pencil and online. The researcher visited the libraries, canteens, and cafeterias of UM, UKM, USM, UPM, and UTM from Monday to Wednesday from October 2018 to December 2018. The researcher was recommended by the librarians to come to the libraries, since many students were available in the libraries from Monday to Wednesday. The subjects were approached in each university's canteen/cafeteria and library and given a piece of paper that contained the online link to the survey. In addition, the researcher attempted to access subjects by seeking assistance from the members of the Indonesian Student Association in each MRU to distribute the questionnaires to international students on campus. Furthermore, the researcher sought assistance from UPM international students to distribute the link via WhatsApp groups to their community in UPM and the other four universities.

\subsection{Demographic Information}

A total of 620 international students who were studying in MRUs were selected as the sample of this study. Satisfaction and importance means were used to determine where the coordinates of each item fell according to international student experience. The average level of satisfaction with the different elements of university foodservice attributes and the average importance for the total sample of five constructs in foodservice attributes were measured. These values were then used to analyze each element in the importance satisfaction grid as a plot. To provide an overview of international students regarding their demographics as well as the nature of their dining experiences, descriptive characteristics of the sample were examined. The respondents' demographics were analyzed in terms of their gender, home country, name of university, level of higher education, current academic year, and year enrolled in the university.

In this study, more male respondents (58.4\%) participated in the survey research than female (41.6\%). The respondents came from various home countries, including Indonesia $(29.8 \%)$, Iraq (11.6\%), Iran (10.3\%), China (9.4\%), Afghanistan (7.7\%), and India (7.2\%). In addition, there were also participants who came from Korea (6\%), Saudi Arabia (5.3\%), the Philippines (3.9\%), Vietnam (3.4\%), Qatar (1.9\%), Somalia (1.1\%), Egypt (1\%), Sri Lanka $(0.9 \%)$, Ethiopia $(0.3 \%)$, and Germany $(0.2 \%)$. Furthermore, the dominant international student group was from UPM (26\%), followed by UM (19.8\%), USM (19.4\%), UTM (18.4\%), and UKM $(16.6 \%)$. The demographic distribution by higher education level. demonstrated that respondents with a bachelor's degree made up the majority of the total respondents $(43 \%)$, followed by those who were earning a master's degree (41.6\%) and a Ph.D. (15.5\%). It was revealed that $30.5 \%$ of the respondents were in the second year of their program, whereas those who were in the third year made up $27.6 \%$ of the total respondents. The participants who answered "other" were $20.8 \%$, meaning that the respondents had studied more than four years since enrolling in the program. The data showed $16.6 \%$ of respondents were in the fourth year of their program, whereas only $4.5 \%$ respondents were university students in their first year. In summary, the participants of this study were mainly undergraduate international students who were studying in one of these research universities: UM, UPM, UKM, UTM, and USM.

The on-campus eating behavior of international students was measured for the period since the students enrolled at the university. The measurement items are provided in Table 1. With regard to the frequency of visits to the on-campus foodservice outlet(s), most of the respondents $(46.8 \%)$ visited the university canteen daily. Daily customers were double those who visited the foodservice outlet(s) monthly (23.2\%), and monthly customers were fewer than the respondents who visited the university cafeteria(s) weekly (30\%). 
Table 1. International students' on-campus eating behavior $(n=620)$.

\begin{tabular}{lcc}
\hline Items & Frequency & Percentage (\%) \\
\hline Frequency of visit & & \\
Daily & 186 & 46.8 \\
Weekly & 290 & 30.0 \\
Monthly & 144 & 23.2 \\
Spending for meals per visit & & \\
S5 MYR & 89 & 14.4 \\
6 MYR-10 MYR & 429 & 69.2 \\
>10 MYR & 102 & 16.4 \\
Dining companions & & \\
Alone & 288 & 46.5 \\
Friends & 332 & 53.5 \\
Reason for dining on campus & & 63.2 \\
The price is inexpensive & 568 & 25.5 \\
There is no other option & 230 & 9.1 \\
To socialize/meet friends & 82 & 1.2 \\
The location is convenient & 11 & 0.3 \\
The food is good & 3 & 0.6 \\
Other & 5 & \\
Type of food purchased when dining on campus & & 30.2 \\
Snacks & 243 & 29.6 \\
Meat/Fish/Chicken & 238 & 10.6 \\
Noodle dish & 86 & 9.0 \\
Rice dish & 73 & 8.6 \\
Vegetables/Fruits & 69 & 6.7 \\
Dairy products & 54 & 5.2 \\
Other & 42 &
\end{tabular}

The findings revealed that over half of the participants $(69.2 \%)$ spent their money for meals in the university cafeteria in the range of 6 MYR to 10 MYR per visit, or approximately US \$1.50 to \$2.50. Respondents who spent more than 10 MYR (US \$2.50) took second place (16.4\%) followed by respondents who spent less than/equal to 5 MYR (US \$1.25) per visit. A large group of participants indicated that they dined with friends (53.5\%), with fewer dining alone $(46.5 \%)$. In the section asking the reason why international students eat on campus, the respondents were able to choose more than one answer. Therefore, the most significant reason to eat on campus was found to be the price $(63.2 \%)$. They chose to eat on campus because the meal price was inexpensive. Another significant reason for the respondents was a lack of other options (25.5\%). It is not surprising that most of the students stated that they eat with friends in the university canteen, because $9.1 \%$ of the participants selected socializing or meeting with friends in the canteen, while $1.2 \%$ of the respondents thought the location of the foodservice outlet was convenient for them. Only $0.3 \%$ of the respondents stated that "the food is good" in the university cafeteria. Participants could select the food they normally order, with more than one option for this question. The most common choices were snacks (30.2\%) and meat, fish, or chicken dishes $(29.6 \%) ; 10.6 \%$ of the respondents mentioned that they like to eat rice dishes, such as fried rice, at the university canteen. Therefore, in term of respondents' on-campus eating behavior, the majority of the respondents were daily consumers and they mostly came to the university foodservice outlet(s) because the price was inexpensive and there was no other option. An overview of the cafeterias in the five Malaysian Research Universities is provided in Appendix A.

\section{Results}

\subsection{Overall IPA Grids}

The average value of these five constructs was computed. These values were then used to draw each element on the important satisfaction grid as coordinates. Table 2 illustrates the means of importance and satisfaction (performance) from the five foodservice attributes 
in this study as well as the coordinates of each foodservice attribute in the IPA grid. The variables in the table were based on the order of Quadrant I to Quadrant IV. SPSS 20 for Windows was used as a tool for the analysis.

Table 2. Importance-performance means for five university foodservice variables.

\begin{tabular}{lllll}
\hline Labels & Variables & Satisfaction & Importance & Quadrant \\
\hline FP & Food price & 4.71 & 5.35 & 1 \\
FQ & Food quality & 4.36 & 5.41 & 2 \\
FS & Food selection & 4.24 & 5.04 & 3 \\
IQ & Interactional quality & 4.63 & 5.05 & 4 \\
AQ & Atmospheric quality & 4.55 & 5.16 & 4 \\
\hline
\end{tabular}

As presented in Figure 2, the horizontal ( $x$-axis) axis shows the importance attributes from low to high perceived by international students (overall importance); whereas the vertical axis (y-axis) shows the rate of service satisfaction for international students (overall satisfaction), ranging from low to elevated. The grid is characterized for satisfaction and importance for the five variables. As specified in Table 2, each variable was labeled for easy recognition and to shorten the name while being analyzed in SPSS 20 for Windows. The labels were also applied to each item of the variables, as shown in Table 3.

The Quadrant I component was considered to be highly important and highly satisfied. The main driver of customer satisfaction was the food price (FP), and the management task was to guarantee that college foodservice "keep up the good work". The component was high importance and low satisfaction in Quadrant II. The underperformance of food quality (FQ) located in this quadrant is regarded to reflect the main weaknesses of a product and suggests efforts should be "concentrate here".

Subsequently, the component in Quadrant III was rated of low importance and low satisfaction. Food selection (FS) was the attribute of "low priority". Apart from being comparatively unimportant, its bad performance is obviously not an issue. Efficiency should be enhanced only if Quadrant II (greater priority) does not contain the characteristics and/or if the improvements are not too expensive [35]. Components in Quadrant IV were rated of low importance and high satisfaction. Interactional quality (IQ) and atmospheric quality (AQ) could be viewed as areas of "possible overkill". They were relatively unimportant for the customers, but the service was very good at the university dining facilities.

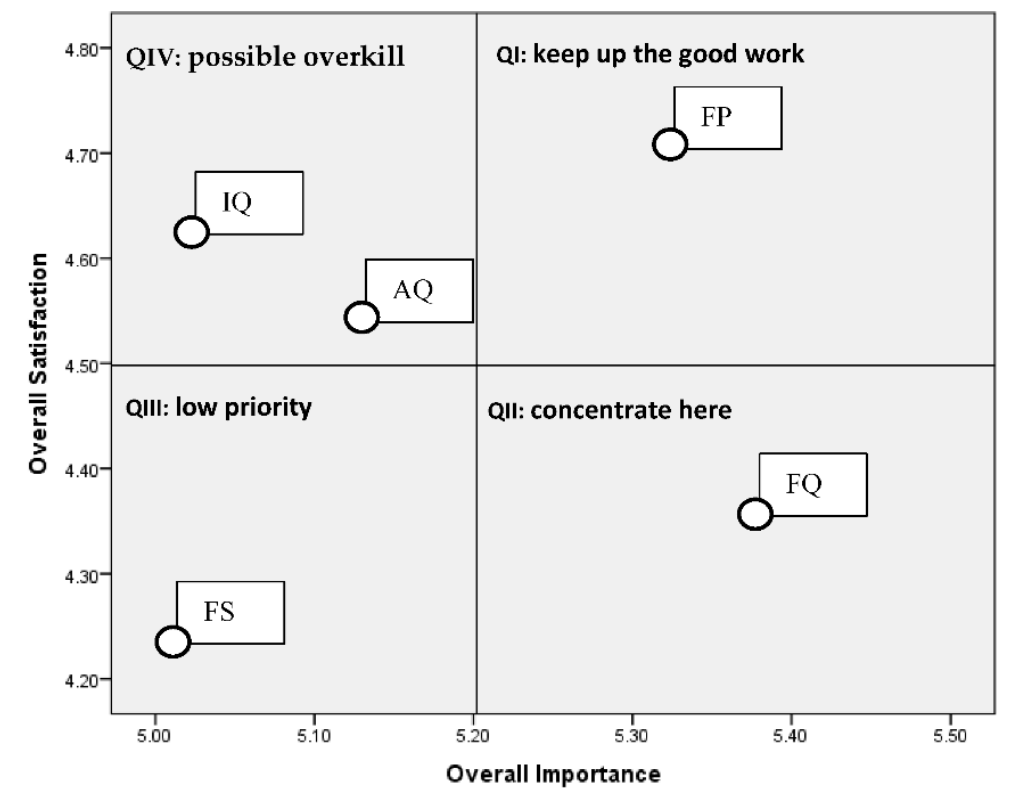

Figure 2. IPA grid for five constructs of university foodservice attributes. 
Table 3. Importance-performance means for 27 university foodservice attributes.

\begin{tabular}{|c|c|c|c|c|}
\hline Labels & Items & Satisfaction & Importance & Quadrant \\
\hline \multicolumn{5}{|c|}{ Interactional quality (IQ) } \\
\hline IQ2 & Respectfulness of the foodservice outlet staff & 4.94 & 5.06 & 1 \\
\hline IQ6 & $\begin{array}{l}\text { Staff knowledge of the food items sold in } \\
\text { foodservice outlet }\end{array}$ & 4.77 & 5.10 & 1 \\
\hline IQ5 & Speed of service in foodservice outlet & 4.72 & 5.07 & 1 \\
\hline IQ1 & $\begin{array}{l}\text { Cleanliness and neatness of staff appearance in } \\
\text { foodservice outlet }\end{array}$ & 4.16 & 5.47 & 2 \\
\hline IQ7 & $\begin{array}{l}\text { Easiness talking to staff (able to answer my } \\
\text { questions) }\end{array}$ & 4.50 & 4.95 & 3 \\
\hline IQ4 & $\begin{array}{l}\text { Professionalism in service delivery in } \\
\text { foodservice outlet }\end{array}$ & 4.38 & 4.83 & 3 \\
\hline IQ3 & Friendliness of the foodservice outlet staff & 4.95 & 4.88 & 4 \\
\hline \multicolumn{5}{|c|}{ Food quality (FQ) } \\
\hline FQ4 & Freshness of food ingredients & 4.38 & 5.74 & 1 \\
\hline FQ2 & Appropriateness of food flavor & 4.36 & 5.46 & 2 \\
\hline FQ1 & Nutritional benefits of food items & 4.36 & 5.45 & 2 \\
\hline FQ5 & Food hygiene and safety & 4.29 & 5.50 & 2 \\
\hline FQ6 & Appropriateness of food temperature & 4.36 & 5.33 & 3 \\
\hline FQ3 & Attractiveness of food items displayed & 4.42 & 4.97 & 4 \\
\hline \multicolumn{5}{|c|}{ Atmospheric quality (AQ) } \\
\hline AQ1 & Seat availability & 4.99 & 5.61 & 1 \\
\hline $\mathrm{AQ} 2$ & Convenience of service hours & 4.94 & 5.43 & 1 \\
\hline AQ5 & Cleanliness of the foodservice outlet & 4.38 & 5.65 & 2 \\
\hline AQ3 & Decoration of the foodservice outlet & 4.51 & 4.90 & 3 \\
\hline $\mathrm{AQ} 4$ & Noise level & 4.45 & 4.89 & 3 \\
\hline AQ6 & Foodservice outlet entertainment, such as music & 4.02 & 4.48 & 3 \\
\hline \multicolumn{5}{|c|}{ Food price (FP) } \\
\hline FP1 & The announcement of food price changes & 4.87 & 5.45 & 1 \\
\hline FP2 & $\begin{array}{l}\text { The reasonableness of the quality of food items } \\
\text { provided for the price paid }\end{array}$ & 4.89 & 5.57 & 1 \\
\hline FP3 & $\begin{array}{l}\text { The reasonableness of the quantity of food } \\
\text { items provided for the price paid }\end{array}$ & 4.37 & 5.02 & 3 \\
\hline \multicolumn{5}{|c|}{ Food selection (FS) } \\
\hline FS2 & The variety of food served & 4.37 & 5.23 & 1 \\
\hline FS3 & The choices of food to meet my religious needs & 5.26 & 5.47 & 1 \\
\hline FS1 & $\begin{array}{l}\text { The choices of food to meet my cultural } \\
\text { preferences }\end{array}$ & 4.16 & 5.07 & 2 \\
\hline FS4 & The selection of food to make me feel at home & 3.63 & 4.89 & 3 \\
\hline FS5 & $\begin{array}{l}\text { The selection of food is similar to that in my } \\
\text { home country }\end{array}$ & 3.77 & 4.56 & 3 \\
\hline
\end{tabular}

\subsection{Individual IPA Grids}

Each of the five characteristics represent the various component elements. The mean value of importance and satisfaction of each attribute for the 27 items is shown in Table 3. The items in Table 3 are based on the order of Quadrant I to Quadrant IV. Five IPA grids were developed in order for the five characteristics of university foodservices to be analyzed and identified in terms of weaknesses and strengths. For each attribute, the mean values of importance and satisfaction were calculated and used as the coordinates for each individual grid. The crosshairs and the positioning of the axis in the grids were developed as excellent means of importance and satisfaction for each element (see Figure 3). Hence, there were different crossing points for the five IPA grids. 
(1) IPA grid for "interactional quality"

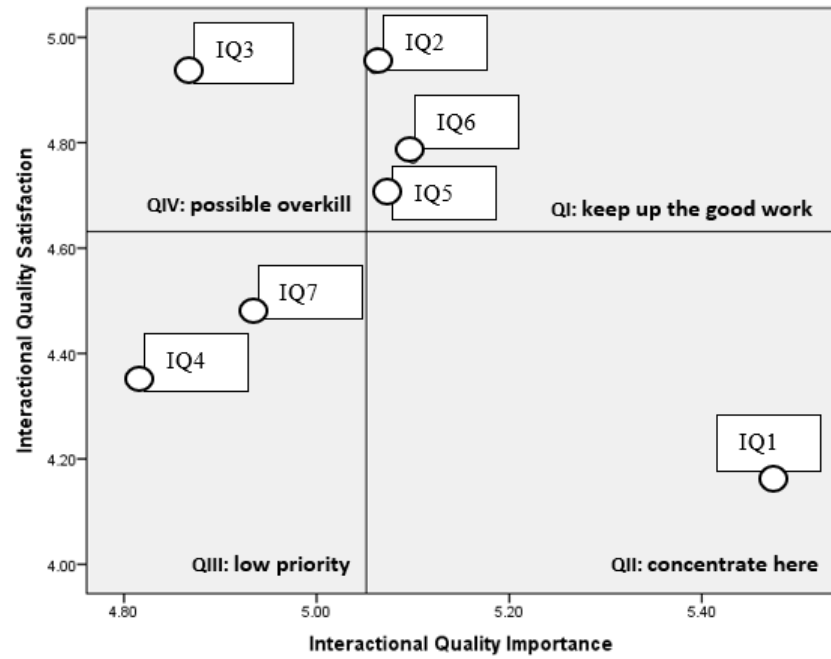

(2) IPA grid for "food quality"

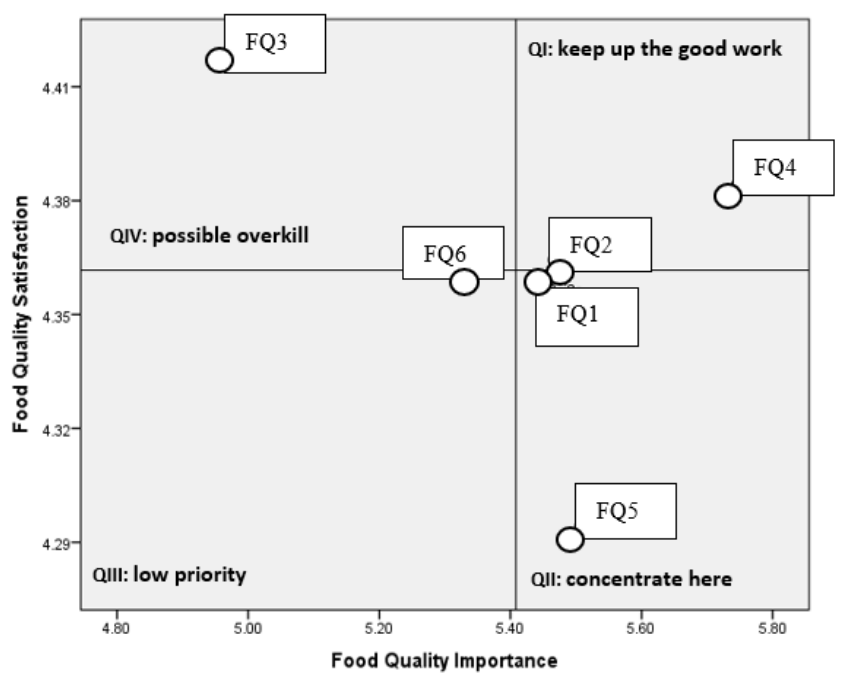

(3) IPA grid for "atmospheric quality"

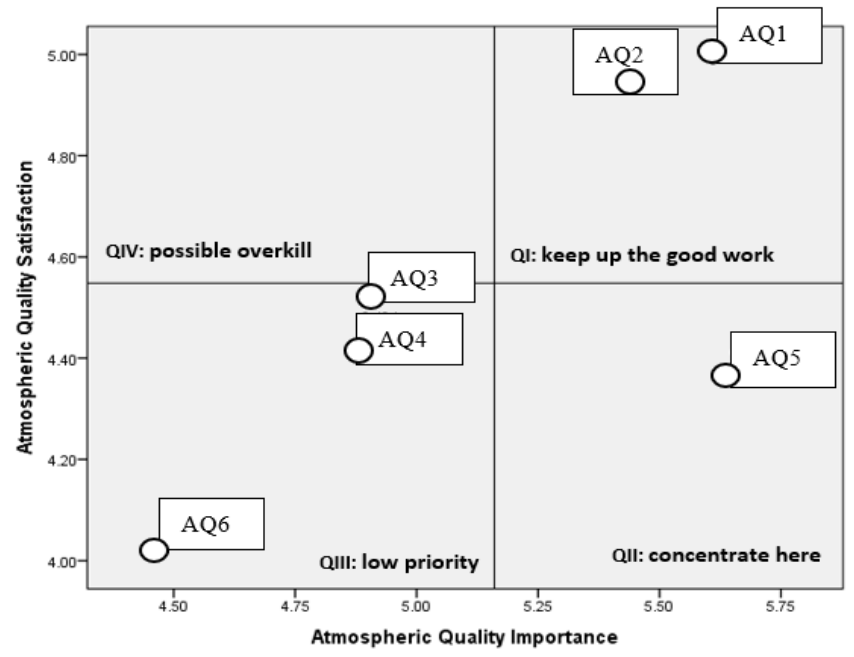

Note:

IQ1: Cleanliness and neatness of staff appearance in foodservice outlet

IQ2: Respectfulness of the foodservice outlet staff

IQ3: Friendliness of the foodservice outlet staff

IQ4: Professionalism in service delivery in foodservice outlet

IQ5: Speed of service in foodservice outlet

IQ6: Staff knowledge of the food items sold in foodservice outlet

IQ7: Ease of talking to staff (able to answer my question)

Note:

FQ1: Nutritional benefits of food items

FQ2: Appropriateness of food flavor

FQ3: Attractiveness of food items displayed

FQ4: Freshness of food ingredients

FQ5: Food hygiene and safety

FQ6: Appropriateness of food temperature
Note:

AQ1: Seat availability

AQ2: Convenience of service hours

AQ3: Decoration of the foodservice outlet

AQ4: Noise level

AQ5: Cleanliness of the foodservice outlets

AQ6: Foodservice outlets entertainment, such as music

Figure 3. Cont. 
(4) IPA grid for "food price"

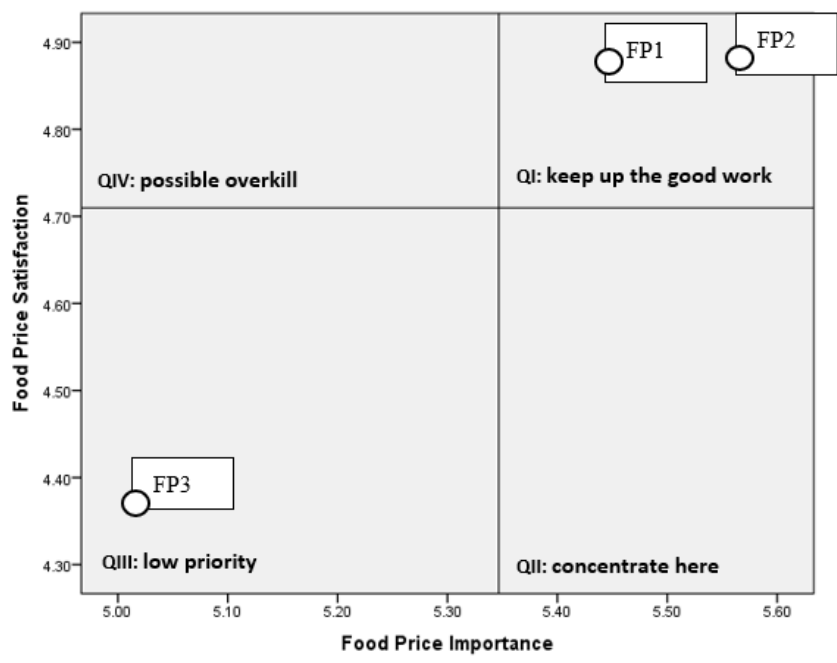

(5) IPA grid for "food selection"

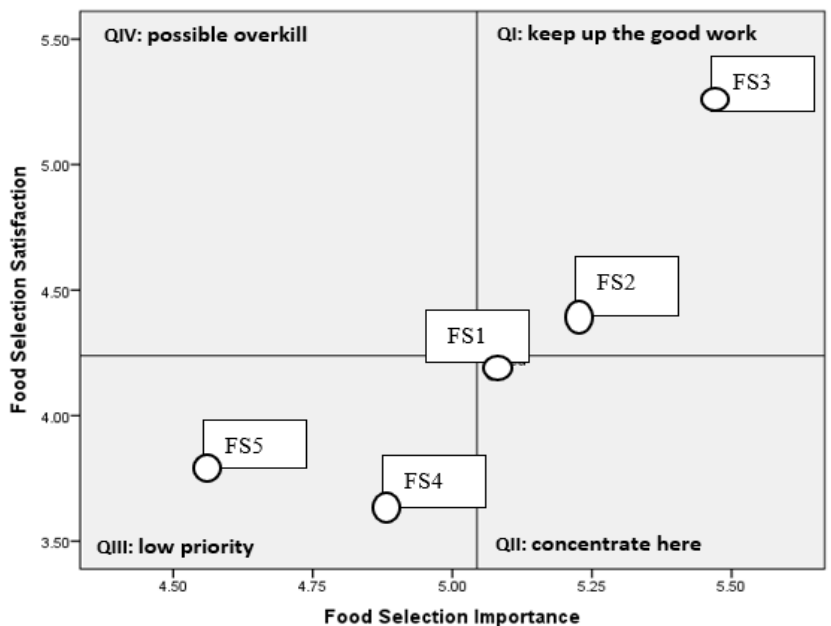

Note:

FP1: The announcement of food price changes

FP2: The reasonableness of the quality of food items provided for the price paid

FP3: The reasonableness of the quantity of food items provided for the price paid

Figure 3. Individual IPA grid for items of university foodservice attributes.

\subsubsection{Interactional Quality}

The international students felt that "cleanliness and neatness of staff appearance in the foodservice outlet" (IQ1) was very important, but indicated low satisfaction with it because this item fell into QII. The respondents indicated that "respectfulness of the foodservice outlet staff" (IQ2), "speed of service in foodservice outlet" (IQ5), and "staff knowledge of the food items sold in foodservice outlet" (IQ6) were very important, and the students were satisfied with the service, as the items fell into QI. If the items in QI are further provided, then the customer can suppose that an organization performs excellent work with a highly significant attribute [57]. The foodservice staff should maintain their excellent job in offering friendly service. "Professionalism in service delivery in foodservice outlet" (IQ4) and "Easiness talking staff (able to answer my question)" (IQ7) indicated no particular intervention was required, because the international students indicated these were of low priority, with the items falling into Quadrant III (QIII). The items appear to be not an issue because their poor performance is comparatively irrelevant. "Friendliness of the foodservice outlet staff" (IQ3) registered in the low importance high satisfaction quadrant (QIV), indicating a potential overuse of efforts and resources expended on this item. In this quadrant, the items were relatively unimportant for international students, but the university foodservice did exceptionally well at providing them. Administrators may 
choose to reassign resources to Quadrant II. Figure 3 shows the IPA grid of interactional quality items.

\subsubsection{Food Quality}

As seen in Figure 3, three items fell into the "concentrate here" quadrant (QII); "Nutritional benefits of food items" (FQ1), "Appropriateness of food flavor" (FQ2), and "Food hygiene and safety" (FQ5) were crucial but students were comparatively unhappy with these items. It can be suggested that attention is needed to improve the satisfaction of international students with these features. "Freshness of food ingredients" (FQ4), which indicates elevated efficiency and high priorities, was situated in the "keep up the good work" quadrant (QI). "Attractiveness of food items displayed" (FQ3) fell into the "possible overkill" quadrant (QIV), showing high satisfaction but low importance. According to this result, one could consider that too much emphasis is placed on this item, considering it is not important to international students. International students were not satisfied with "Appropriateness of food temperature" (FQ6) in university foodservice. However, it was a low priority, since this was also a relatively low priority for students.

\subsubsection{Atmospheric Quality}

According to Figure 3, international students were less satisfied with "Cleanliness of the foodservice outlets" (AQ5) than with other elements. This dimension was considered by students to be essential, but the output was relatively small. This indicates that efforts for enhancement should be focused on this element. There were three items indicated in "low priority" quadrant (QIII): "Decoration of the foodservice outlet" (AQ3), "Noise level" (AQ4), and "Foodservice outlet entertainment, such as music" (AQ6). Under the "keep up the good work" category were "Seat availability" (AQ1) and "Convenience of service hours" (AQ2). No component was located in the "possible overkill" quadrant in this attribute.

\subsubsection{Food Price}

As shown in Figure 3, two items of food price attributes were in the "keep up the good work" quadrant: "The announcement of food price changes" (FP1) and "The reasonableness of the quality of food items provided for the price paid" (FP2). These characteristics were highly important and satisfactory for global students. While "The reasonableness of the quantity of food items provided for the price paid" (FP3) was rated comparatively poor, satisfaction was also rated insufficient. These characteristics did not involve any extra resources because of the small salience; if resources were limited, they could be used if needed in different fields that were more relevant.

\subsubsection{Food Selection}

As depicted in Figure 3, "The variety of foods served" (FS2) and "The choices of foods permit me to meet my religious needs" (FS3) were located in Quadrant I. International students felt these items were both important and satisfactory; management ensured that these fell into the category of "keep up the good work". "The choices of food meet my cultural preferences" (FS1) was located in Quadrant II. This feature was very important but the respondents felt unsatisfied, which represented a priority for management action. The administrators of university foodservice should concentrate on this point. This food selection item was deemed important, but international students were only slightly satisfied with it. The management therefore required special attention for this point. An additional two items were shown in Quadrant III: "The selection of food makes me feel at home" (FS4) and "The selection of food is similar to that in my home country" (FS5).

\section{Discussion and Implications}

In accordance with the results of this study, food price attribute was the key driver of international student satisfaction, and management's job is to ensure that the university 
foodservice "keeps up the good work". Two of three foodservice components, "The announcement of food price changes (FP1)" and "The reasonableness of the quality of food items provided with the price paid (FP3)" emerged as the most satisfactory factors, indicating that international students held highly positive perceptions of university foodservice in these areas. These two components were highly important in attracting international students to eat on campus. Thus, the food prices are critical elements affecting international students' satisfaction. Foodservice operators are advised to focus on these aspects in their promotional efforts of university foodservice in order to capitalize on their importance. Based on the importance-performance analysis, food quality attributes emerged as very important, but international students were not satisfied. Food quality situated in Quadrant II was considered to be underperforming and, as such, represents the product's major weaknesses. Hence, the managers must concentrate on this attribute. "Nutritional benefits of food items (FQ1)", "Appropriateness of food flavor (FQ2)", and "Food hygiene and safety (FQ5)" were three components of food quality that were very important, but international students were less satisfied with these items. It can be suggested that these items should be taken into consideration for cafeteria administrators and can be addressed by providing more vegetables dishes, the availability of juices, etc. University foodservice managers can collaborate with food science and technology departments in their university to create a variety of healthy foods with reasonable prices in the university cafeteria.

On the other hand, "Freshness of food ingredients (FQ4)" was located in "keep up the good work" quadrant, indicating high performance and high priority. The participants felt that this dimension was crucial, and the university operators seemed to perform very effectively in its delivery. The implication is that continued resources should be directed towards improving this item. The college foodservice providers should guarantee that ingredients used for student meals are checked periodically in the college cafeteria for each kitchen counter. The checked components can consist of the expiry date, freshness of the vegetables/spices and herbs, refrigeration methods used in the cafeteria, etc. Meanwhile, two foodservice attributes were relatively unimportant to the international students, but the university foodservice performed very well; these were interactional quality and atmospheric quality. This suggests a possible over-employment of efforts and resources being spent on these attributes. Management may wish to reassign resources to the attributes associated with food quality. In interactional quality items, the foodservice providers must consider the cleanliness and neatness of staff. This item was indicated as very important but had low satisfaction by international students. The findings suggest that special attention is needed for these highly significant performance foodservice components. University foodservice operators need to improve upon these features. The operators can provide training to university foodservice staff in order to increase their knowledge of hygiene and safety. In addition, operators also can conduct audits of the staff.

Meanwhile, in atmospheric quality components, international students deemed "Cleanliness of the foodservice outlets (IQ1)" particularly important yet were less satisfied with it relative to other items. Foodservice managers in the MRUs should pay particular attention to improving international students' satisfaction with this item because it was positioned in the quadrant of "concentrate here". This aspect was regarded as very important for international students, but the production was comparatively low. This should be the focus of improvement initiatives. Foodservice operators should conduct a regular inspection of the appearance of their staff, including the use of gloves when serving meals, the use of safety shoes, the use of aprons, wearing cooking caps to avoid hair falling in the meals, etc. Nevertheless, "keep up the good work" was achieved for "Seat availability" (AQ1) and "Convenience of service hours" (AQ2). The items in Quadrant I are usually concerned with the operation of foodstuffs and should continue to improve the efficiency level. It would therefore be realistic for university foodservice managers to keep on focusing on these attributes in foodservice development on campus. For the food selection components, international students felt they were both important and satisfactory in terms of food variety served and food choices to meet their religious needs. The management should ensure 
these items continue to "keep up the good work". Nonetheless, the international students felt that food choices that met their cultural preferences were very important, but they were unsatisfied with the performance. Thus, the university foodservice administrators should focus on this, including increasing the variety of food (e.g., shawarma, takoyaki, sushi, tacos, etc.) to reflect more diversified ethnicity and age groups and to support students with special dietary needs and providing a variety of foods from various countries. The university foodservice operators can collaborate with the international student association and food departments to create, innovate, and provide food choices that can be accepted by international students and be reasonably priced.

The findings are useful in forecasting international student satisfaction and offering good empirical evidence for the importance-performance analysis, which assumes that attribute performance influences international student satisfaction less when the attribute's self-stated significance is poor. If international student satisfaction is highly influenced by attribute performance, the attribute's self-assessed value is high. The findings of this research provide a better understanding of the international students' satisfaction with oncampus foodservice in MRUs. Results from IPA also assist in determining how international students perceive the quality of the key competencies of on-campus foodservices and identify fields in which improvements are further required. The results also are useful in determining how to enhance international students' satisfaction with foodservice attributes in the university.

Overcoming these limitations can provide guidance for future research. First, Indonesian students made up the majority of those who participated in this research. The result could be a non-response factor, which was implemented owing to a lack of representation in the population of these non-respondents. It was possible that most of the perception was based on differences in taste or culture. This may lead to an upward bias in responses. Consequently, the findings of studies on the population of interest should be implemented to counter these limitations. Second, international students in this study came from different cultures around the world. Culture can affect consumer thinking and perceptions, as Li [46] has indicated. For this reason, future research may seek to determine how the relations between the studies differ in terms of service delivery and students of distinct backgrounds and cultural variables. This research is an exciting expansion. Furthermore, the practical data acquired will certainly help food operators in understanding global students' distinctive requirements. Third, the research results may not be generalizable outside this population, because only international students from Malaysian research universities were included in the study population. It is critical that comparative studies be repeated at other Malaysian universities in order to increase generalization. However, the results of the study do not guarantee the same outcomes when various conditions for allocations of different international student population groups are applied. Approved by any clear findings regarding alternative population segmentation criteria, similar assessments must be made for comparative reasons.

\section{Conclusions}

The empirical findings of this research demonstrated that interactional quality, food quality, atmospheric quality, food price, and food selection attributes in each IPA quadrant were positioned by the mean values of importance and performance. The results are effective in predicting international student satisfaction and provide strong empirical support for the importance-performance analysis, which assumes that international student satisfaction will be influenced less by attribute performance when the self-stated importance of the attribute is low. Where international student satisfaction is influenced by attribute performance, the self-stated importance of the attribute is high. According to the results of the importance-performance analysis, food price was the key driver of international student satisfaction, since the students felt that food price attribute was important and they were satisfied with the attribute. Unfortunately, food quality was considered to be underperforming and, as such, represents the product's major weakness. 
Thus, this attribute should be addressed by foodservice managers. Subsequently, food selection was an attribute of low priority. Interactional quality and atmospheric quality could be viewed as areas of performance that were relatively unimportant to international students; however, the university foodservice performed very well in these areas. The importance-performance analysis technique examined international student satisfaction with on-campus foodservice. The findings of this research provide better understanding of international students' satisfaction with on-campus foodservice in MRUs, which can help to meet university quality standards. Results from the IPA can also help to determine how international students perceive the quality of the key competencies of on-campus foodservices and identify fields in which improvements are further required.

Author Contributions: Conceptualization, A.Z.A. and B.-L.C.; methodology, A.Z.A. and B.-L.C.; writing-original draft preparation, A.Z.A.; writing-review and editing, B.-L.C. and H.H.; visualization, A.Z.A.; supervision, H.H. and A.R.; project administration, A.Z.A. and B.-L.C. All authors have read and agreed to the published version of the manuscript.

Funding: This research received no external funding.

Institutional Review Board Statement: Because of the observational nature of the study, and in the absence of any involvement of therapeutic medication, no formal approval of the institutional review board of the local ethics committee was required. Nonetheless, all subjects were informed about the study and participation was on a voluntary basis. The study was conducted in accordance with the Declaration of Helsinki.

Informed Consent Statement: Not applicable.

Conflicts of Interest: The authors declare no conflict of interest.

\section{Appendix A}

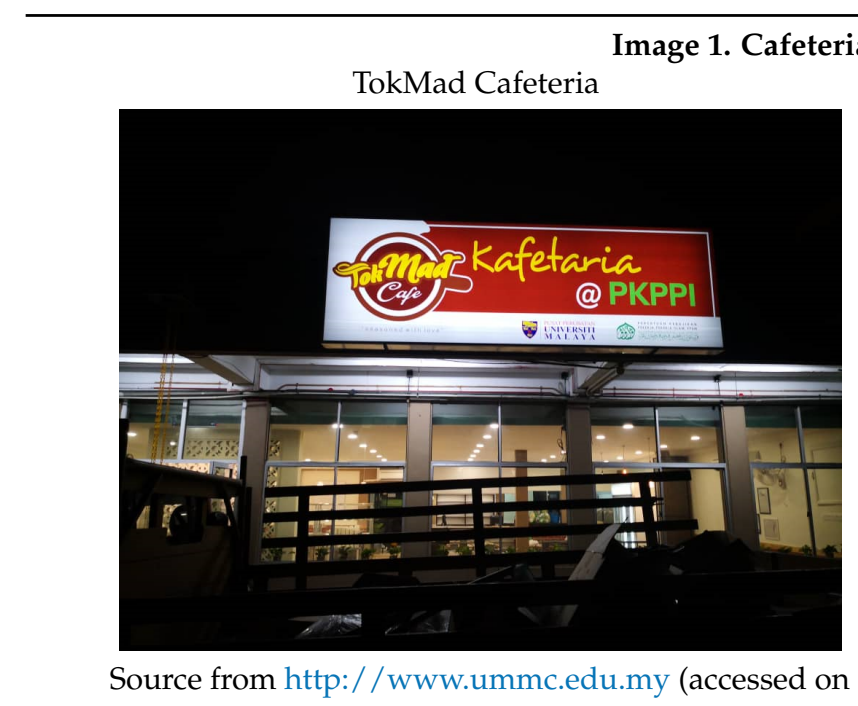
26 May 2021)
TokMad Cafeteria

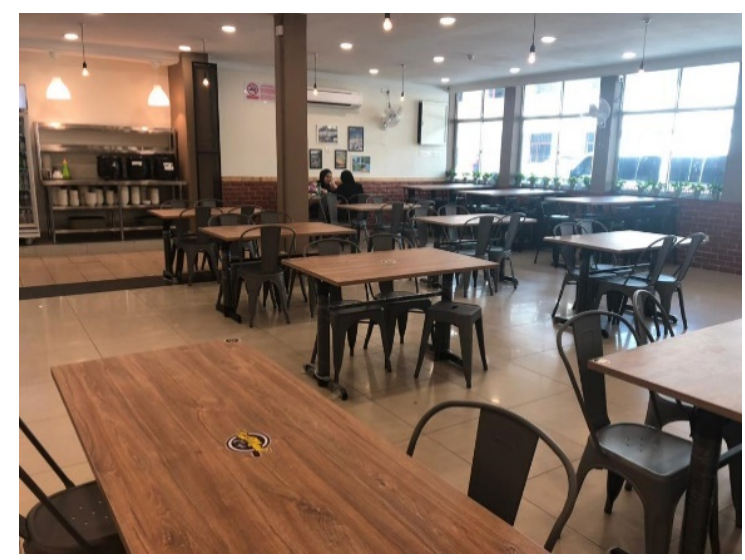

Source from http:/ / www.ummc.edu.my (accessed on 26 May 2021) 
Image 2. Cafeteria of Universiti Kebangsaan Malaysia (UKM)

Cafeteria Pusanika

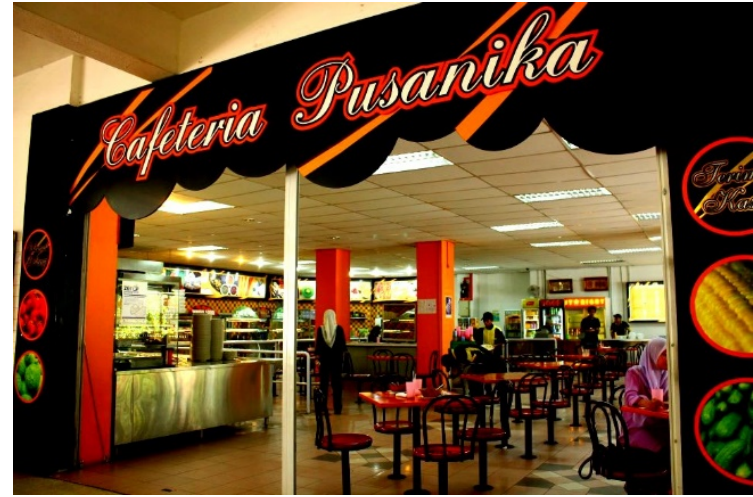

Source from http:/ / www.ukm.edu.my (accessed on 26 May 2021)
Pendeta Zaba College Cafeteria

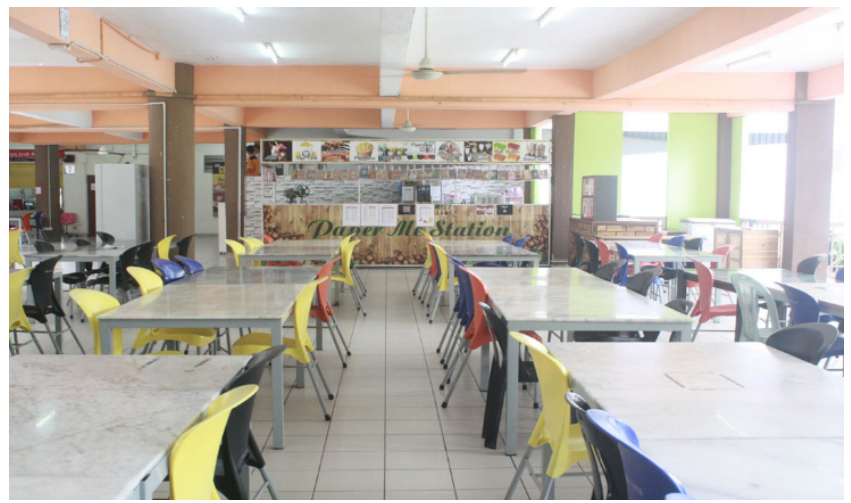

Source from http:/ / www.ukm.edu.my (accessed on 26 May 2021)

Image 3. Cafeteria of Universiti Sains Malaysia (USM)

Subaidah Restaurant

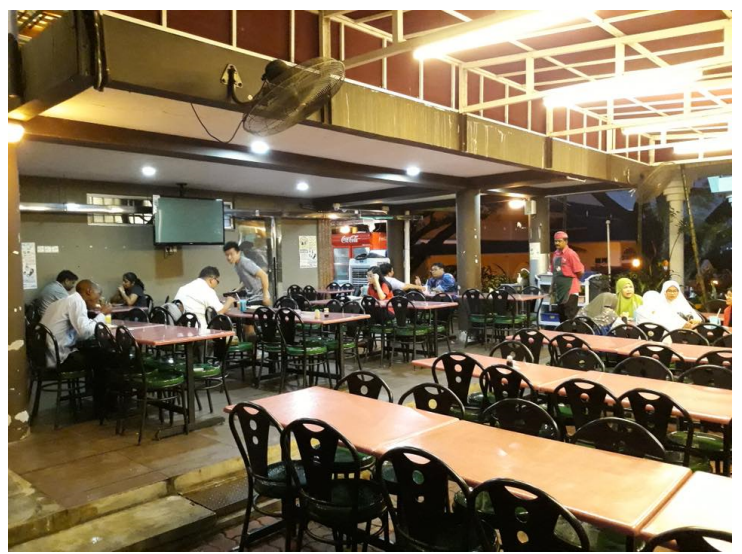

Source from https:/ / news.usm.my (accessed on 26 May 2021)
Subaidah Restaurant

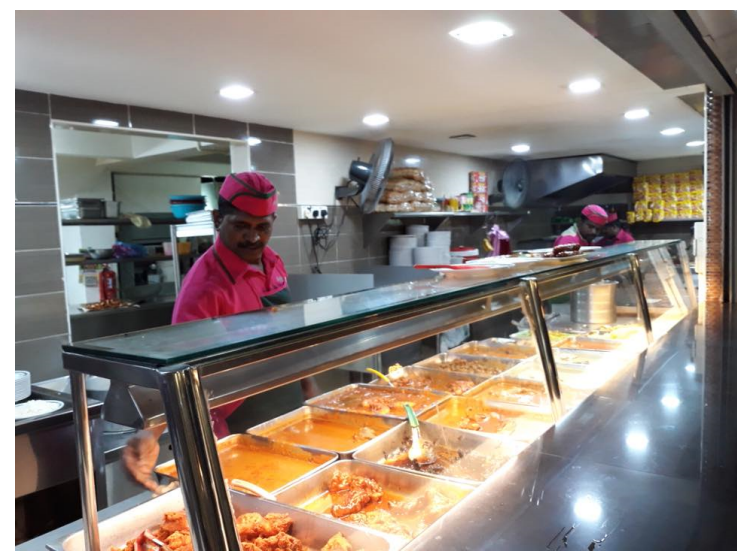

Source from https: / / news.usm.my (accessed on 26 May 2021)

Image 4. Cafeteria of Universiti Putra Malaysia (UPM)

Kolej 13 Cafeteria

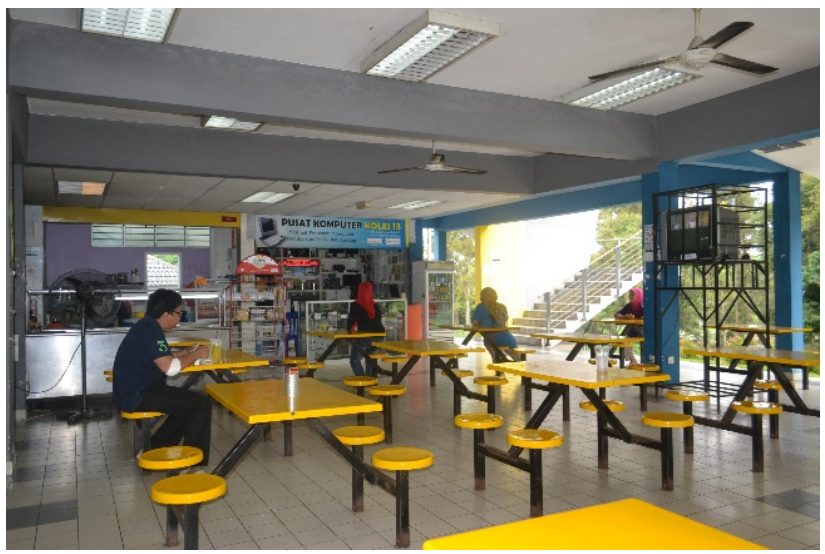

Source from https:/ / k13.upm.edu.my (accessed on 26 May 2021)
Kolej 16 Cafeteria

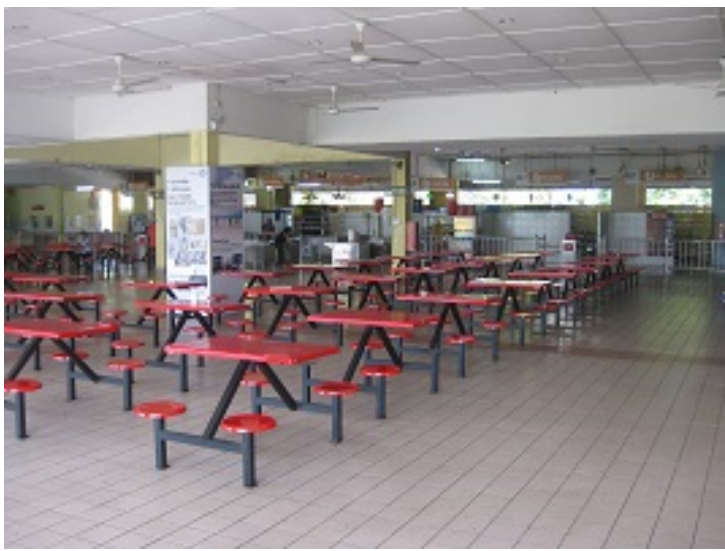

Source from https: / k16.upm.edu.my (accessed on 26 May 2021) 


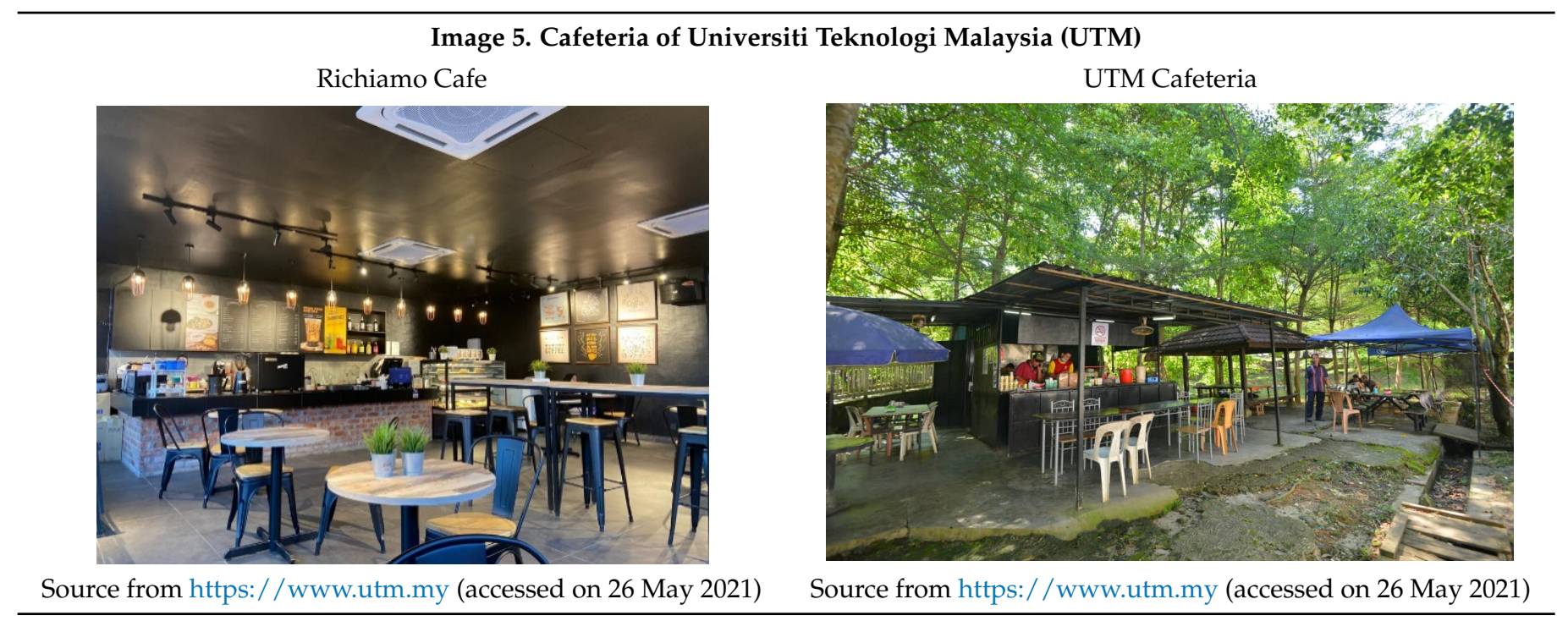

\section{References}

1. Singh, J.K.N.; Schapper, J.; Jack, G. The importance of place for international students' choice of university: A case study at a Malaysian university. J. Stud. Int. Educ. 2014, 18, 463-474. [CrossRef]

2. Arambewela, R.; Hall, J. An empirical model of international student satisfaction. Asia Pac. J. Mark. Logist. 2013, 21, 555-569. [CrossRef]

3. Khairani, A.Z.; Razak, N.B. Assessing factors influencing students' choice of Malaysian Public University: A Rasch model analysis. Int. J. Appl. Psychol. 2013, 3, 19-24.

4. Lee, K.-W.; Yuan, J.; Hwang, J.-S.; Kim, H.-S. Doctoral students' selection intention in Hospitality and Tourism Management (HTM) programs in the United States. J. Hosp. Leis. Sport Tour. Educ. 2012, 11, 140-150. [CrossRef]

5. Ezeokoli, R.N.; Ayodele, K.O. Dimensions of service quality encountered by students on sustainability of higher education in Nigeria. Dimensions 2014, 4, 147-156.

6. Klassen, K.; Trybus, E.; Kumar, A. Planning food services for a campus setting. Int. J. Hosp. Manag. 2005, 24, 579-609. [CrossRef]

7. Abdullah, D.; Rozario, F. Influence of service and product quality towards customer satisfaction: A case study at the staff cafeteria in the hotel industry. Int. J. Econ. Manag. 2009, 53, 185-190.

8. Al-Tit, A.A. The effect of service and food quality on customer satisfaction and hence customer retention. Asian Soc. Sci. 2015, 11, 129. [CrossRef]

9. Amelia, M.; Garg, A. The first impression in a fine dining restaurant. A study of $C$ restaurant in Tampere, Finland. Eur. J. Tour. Res. 2016, 7, 100-111. [CrossRef]

10. Andaleeb, S.; Caskey, A. Satisfaction with food services: Insight from a college cafeteria. J. Foodserv. Bus. Res. 2007, 10, 51-65. [CrossRef]

11. Bilgin, Y. The effect of service quality, customer satisfaction and customer loyalty on word of mouth marketing in restaurants. J. Bus. Res. Türk. 2017, 9, 33-62. [CrossRef]

12. El-Said, O.A.; Fathy, E.A. Assessing university students' satisfaction with on-campus cafeteria service. Tour. Manag. Perspect. 2015, 16, 318-324. [CrossRef]

13. Kumar, S.; Bhatnagar, D. Effect of food and service quality on customer satisfaction a study of 3 star hotels in Punjab region. Int. J. Sales Mark. Manag. Res. Dev. 2017, 7, 35-48. [CrossRef]

14. Taylor, R.; Shanka, T. Importance of wine festival characteristics in determining first-time and repeat visitors' festival experience. In Proceedings of the Australian and New Zealand Marketing Academy Conference, Dunedin, New Zealand, 3 December 2007; pp. 58-63.

15. Liang, X.; Zhang, S. Investigation of customer satisfaction in student foodservice: An example of student cafeteria in NHH. Int. J. Qual. Serv. Sci. 2009, 1, 113-124. [CrossRef]

16. Drummond, K.; Brefere, L. Nutrition for Foodservice and Culinary Professionals; John Wiley \& Sons, Inc: New York, NY, USA, 2001.

17. Zainol, N.; Seladorai, J. What matters most? Factors influencing international students' satisfaction towards cafetaria foods. Mediterr. J. Soc. Sci. 2016, 7, 295-302. [CrossRef]

18. Lee, K.A.; Lyu, E.S. Importance-performance analysis (IPA) of university foodservice quality by customer group according to the foodservice satisfaction and customer loyalty. J. Korean Soc. Food Sci. Nutr. 2019, 21, 389-405. [CrossRef]

19. Kim, W.G.; Ng, C.Y.; Kim, Y.-S. Influence of institutional DINESERV on customer satisfaction, return intention, and word-of-mouth. Int. J. Hosp. Manag. 2009, 28, 10-17. [CrossRef]

20. Abd Ghani, F.; Zahari, M.S.M.; Ramli, N.; Jusoff, K.; Zaini, Z.M.M.; Hamid, M.; Samsudin, A.; Ngali, N.; Rahmat, N. Service at UiTM residential hostel cafeterias-Is it satisfactory? World Appl. Sci. J. 2011, 12, 8-13. 
21. Nadzirah, S.; Karim, S.A.; Ghazali, H.; Othman, M. University foodservice: An overview of factors influencing the customers'. Int. Food Res. J. 2013, 20, 1459-1468.

22. Abdullah, S.; Mansor, N.; Mohamed, M. Exploring the major determinants of student satisfaction on university cafeteria foodservices: A Malaysian case. Interdiscip. J. Res. Bus. 2012, 2, 62-73.

23. Yee, C.P.; Mokhtar, A.H. Factors influencing international students' choice of study destination at private higher education institutions in Malaysia. In Proceedings of the International Conference on Language, Communication and Education 2014 (LANCOMME2014)Sunway Hotel \& Spa, Bandar Sunway, Malaysia, 3-4 December 2014.

24. Smith, R.A.; McNeil, A.W.; Ali, F. Students' perceptions and behavior toward on-campus foodservice operations. Int. Hosp. Rev. 2020, 34, 13-28. [CrossRef]

25. Garg, A.; Kumar, J. Exploring customer satisfaction with university cafeteria food services. An empirical study of temptation restaurant at Taylor's University, Malaysia. Eur. J. Tour. Hosp. Recreat. 2017, 8, 96-106. [CrossRef]

26. Kim, H.-S.; Lee, S.-M.; Yuan, J. Assessing college students' satisfaction with university foodservice. J. Foodserv. Bus. Res. 2012, 15, 39-48. [CrossRef]

27. Raman, S.; Chinniah, S. An Investigation on Higher Learning Students Satisfaction on Food Services at University Cafeteria. Int. J. Commer. IT Manag. 2011, 1, 12-16.

28. Chang, D.M.-L.; Suki, N.M. Students' Satisfaction of Food Services at the University Cafeteria: A Comparative Study Via PLS Approach. Int. J. Eng. Technol. 2018, 7, 61-66. [CrossRef]

29. Kaura, V.; Prasad, D.; Sharma, S. Service quality, service convenience, price and fairness, customer loyalty, and the mediating role of customer satisfaction. Int. J. Bank Mark. 2015, 33, 404-422. [CrossRef]

30. Mensah, I.; Mensah, R. Effects of Service Quality and Customer Satisfaction on Repurchase Intention in Restaurants on University of Cape Coast Campus. J. Tour. Herit. Serv. Mark. 2018, 4, 27-36. [CrossRef]

31. Li, G. Difficulties facing university catering service work and response. Sci. Infor. Tech. 2008, 14, 72-73.

32. Ha, J.; Jang, S. Effects of service quality and food quality: The moderating role of atmospherics in an ethnic restaurant segment. Int. J. Hosp. Manag. 2010, 29, 520-529. [CrossRef]

33. Namkung, Y.; Jang, S. Are highly satisfied restaurant customers really different? A quality perception perspective. Int. J. Contemp. Hosp. Manag. 2008, 20, 142-155. [CrossRef]

34. McLachlan, D.; Justice, J. A grounded theory of international student well-being. J. Theory Constr. Test. 2009, 13, 27-32.

35. Fordham, T. Pedagogies of cultural change: The rotary international youth exchange program and narratives of travel and transformation. J. Tour. Cult. Chang. 2006, 3, 143-159. [CrossRef]

36. Andrade, M. International students in English-speaking universities: Adjustment factors. J. Res. Int. Educ. 2006, 5, 131-154. [CrossRef]

37. Thomas, K.; Althen, G. Counseling foreign students. In Counseling Across Cultures, 3rd ed.; Pedersen, P.B., Draduns, J.G., Lonner, W.J., Trimble, J.E., Eds.; University of Hawaii Press: Honolulu, HI, USA, 1989; pp. 205-241.

38. Holligan, S.; Yi, S.; Kanetkar, V.; Haines, J.; Dergham, J.; Royall, D.; Brauer, P. Preferences for vegetables among university foodservice users: A survey to inform nudge-based interventions. Br. Food J. 2019, 121, 3338-3349. [CrossRef]

39. Lin, J.; Yi, J. Asian international students' adjustment: Issues and program suggestions. Coll. Stud. J. 1997, 31, 473-479.

40. Tseng, W.; Newton, F. International students' strategies for well-being. Coll. Stud. J. 2002, 36, 50-62.

41. Ruetzler, T.; Taylor, J.; Hertzman, J. Adaptation and international students' perceptions of on-campus foodservice. Br. Food J. 2012, 114, 1599-1612. [CrossRef]

42. Kau, A.-K.; Loh, E.W.-Y. The effects of service recovery on consumer satisfaction: A comparison between complainants and non-complainants. J. Serv. Mark. 2006, 20, 101-111. [CrossRef]

43. Locher, J.L.; Yoels, W.C.; Maurer, D.; Van Ells, J. Comfort foods: An exploratory journey into the social and emotional significance of food. Food Foodways 2005, 13, 273-297. [CrossRef]

44. Garg, A. Mechanic clues vs. humanic clues: Students' perception towards service quality of fast food restaurants in Taylor's University campus. Procedia Soc. Behav. Sci. 2014, 144, 164-175. [CrossRef]

45. Ali, H.; Li, M.; Hao, Y. Purchasing behavior of organic food among Chinese university students. Sustainability 2021, 13, 5464. [CrossRef]

46. Mill, R.C. Restaurant Management: Customers, Operations, and Employees; Prentice Hall: Hoboken, NJ, USA, 2000.

47. Martilla, J.; James, J. Importance-Performance analyses. J. Mark. 1977, 41, 77-79. [CrossRef]

48. Matzlera, K.; Bailom, F.; Hinterhuber, H.H.; Renzl, B.; Pichler, J. The asymmetric relationship between attribute-level performance and overall customer satisfaction: A reconsideration of the importance-performance analysis. Ind. Mark. Manag. 2004, 33, 271-277. [CrossRef]

49. Chua, B.-L.; Goh, B.; Huffman, L.; Jai, C.; Karim, S. Cruise passengers' perception of key quality attributes of cruise lines in North America. J. Hosp. Mark. Manag. 2016, 25, 346-371. [CrossRef]

50. Sampson, S.; Showalter, M. The performance-importance response function: Observations and implications. Serv. Ind. J. 1999, 19, 1-25. [CrossRef]

51. Park, S.-E.; Cho, M.-S.; Oh, J.E. A study on the improvement of tangible and intangible foodservice facilities in complex cultural spaces. J. Korean Soc. Food Cult. 2020, 31, 149-160. [CrossRef] 
52. Esmailpour, J.; Aghabayk, K.; Vajari, M.A.; De Gruyter, C. Importance-Performance Analysis (IPA) of bus service attributes: A case study in a developing country. Transp. Res. Part A Policy Pract. 2020, 142, 129-150. [CrossRef]

53. Peira, G.; Beltramo, R.; Pairotti, M.B.; Bonadonna, A. Foodservice in a UNESCO Site: The restaurateurs' perception on communication and promotion tools. Sustainability 2018, 10, 2911. [CrossRef]

54. Hansen, E.; Bush, R. Understanding customer quality requirements: Model and application. Ind. Mark. Manag. 1999, 28, 119-130. [CrossRef]

55. Tzeng, G.-H.; Chang, H.-F. Applying importance-performance analysis as a service quality measure in foodservice industry. J. Technol. Manag. Innov. 2011, 6, 106-115. [CrossRef]

56. Gemmel, P. Delivering excellent service quality in aviation: A practical guide for internal and external service providers. Int. J. Serv. Ind. Manag. 2007, 18, 443-444. [CrossRef]

57. Chi, G. A Study of Developing Destination Loyalty Model; ProQuest Dissertations Publishing: Oklahoma, OK, USA, 2005. 